\title{
SOCIAL NORMS AND THE RULE OF LAW: AN APPLICATION TO FAILED STATES
}

\author{
by Keith Jakee*, Stephen Jones-Young**
}

\section{Introduction}

Failed states are terrible places to live. They have the lowest levels of development as measured by literacy, child mortality, clean water, miles of paved road, and most other quality-of-life indicators. They suffer from ongoing economic stagnation ${ }^{1}$, central banks fail to control inflation ${ }^{2}$, governments are unable to collect taxes ${ }^{3}$, the police and military languish ${ }^{4}$, and these nations tend to be highly-dependent upon foreign aid 5 . The citizens of failed states are frequently harassed, or worse, by armed non-state and state actors ${ }^{6}$.

* Wilkes Honors College, Florida Atlantic University.

** United States Coast Guard.

The Authors thank Demi Fink, Rebecca Peter, Fabio Rosa and Sydney Rose for research assistance. Emily Heithcock, Jorge Jraissati, and Kenneth Kalczuk provided helpful comments.

1 R. Rotberg, Failed States, Collapsed States, Weak States: Causes and Indicators, in R. Rotberg (ed.), "State Failure and State Weakness in a Time of Terror", Washington DC, Brookings Institution Press, 2003, p. 8.

2 R. Rotberg, Failed States, Collapsed States, Weak States: Causes and Indicators, cit., p. 3 .

3 J. WIDNER, States and Statelessness in Late Twentieth-Century Africa, in "Daedalus", Summer, 1995, p. 136.

4 R. Rotberg, Failed States, Collapsed States, Weak States: Causes and Indicators, cit., p. 6.

5 T.V. PAUl, State Capacity and South Asia's Perennial Insecurity Problems, in T.V. PAul (ed.), "South Asia's Weak States: Understanding the Regional Security Predicament", Stanford, Stanford University Press, 2010, pp. 3-27.

6 R. Rotberg, The New Nature of Nation-State Failure, in "The Washington Quarterly", Summer, 2002, pp. 85-96. 
According to a prominent group of international relations scholars, it is pervasive "internal insecurity" - or the lack of citizen protectionthat is the underlying condition that determines whether a state is failed 7 . Another group of researchers, focusing on the economics of development more broadly, emphasize institutional "capacity," or the state's ability to provide various kinds of public goods, not least of which is citizen protection ${ }^{8}$.

Thus, while operating in different intellectual spheres, both sets of scholars focus on the formal expression of institutions, such as laws and constraints on the government, and both tend to advocate bolstering these institutions through what is often referred to as "capacity building." This capacity building includes external interventions for some observers. The logic is that building capacity will strengthen the state's monopoly over violence and thus solve the problem of internal chaos?.

Emphasizing the derelict state of formal rules and formal institutions in failed states is essentially a call for implementing — or strengthening - the "rule of law" commonly understood to include, inter alia, democratically-legislated rules (rather than capricious autocratic decisions), transparent rules (over non-transparent ones), and the equal treatment of individuals (as opposed to the granting of special privileges to some $)^{10}$. But this focus on the formal aspects of the rule of law has also meant - explicitly or implicitly — de-emphasizing the role of informal institutions. For example, Acemoglu and Robinson assert that informal institutions - what they call the "culture hypothesis"-while occasionally "useful," are ultimately not determinative in development

7 See, for example, R. Rotberg, Failed States, Collapsed States, Weak States: Causes and Indicators, cit.; J. WIDNER, States and Statelessness in Late Twentieth-Century Africa, cit., p. 144; L. Brock, H-H. Holm, G. Sørensen, M. Stohl, Fragile States: Violence and the Failure of Intervention, Malden, Polity Press, 2012, p. 16.

8 See, for example, D. Acemoglu, J. Robinson, Why Nations Fail: The Origins of Power, Prosperity, and Poverty, New York, Currency, 2012.

9 See, for example, R. Rotberg, Failed States, Collapsed States, Weak States: Causes and Indicators, cit. or S. D. KRASNER. Sharing Sovereignty: New Institutions for Collapsed and Failing States, in "International Security", n. 2, Fall, 2004, pp. 85-120 in the international relations literature, or D. AcEMOGLu, J. RoBinson, Why Nations Fail: The Origins of Power, Prosperity, and Poverty, pp. 80-81 and p. 91 in the economic development literature.

${ }^{10}$ See, for example, F. HAYEK, The Constitution of Liberty, Chicago, University of Chicago Press, 1960 or B. Leoni, Freedom and Law, Toronto, D. Van Nostrand Co., 1961 for extensive definitions and discussions of the rule of law. 
processes because informal social norms are "mostly an outcome of [formal] institutions, not an independent cause" 11 .

What is largely overlooked by this focus on formal systems is the role that informal social norms play in any well-functioning society, a point raised by a number of authors ${ }^{12}$ and one we discuss in more detail in section 3. Our general claim is that, without significant changes in the informal social norms that underpin the rule of law, the centralization or overhaul of national formal institutions in failed states will not be sufficient to establish the rule of law. A simple heuristic, which summarizes our position suggests that the profound developmental issues faced by countries, such as the Democratic Republic of Congo (DRC), cannot be solved by merely rewriting their constitutions, increasing the number of police or judges, intervening militarily, or even doing all three of these simultaneously. Virtually all, from the political leadership to the common citizen, believe that Congolese national law will be ignored unless some state authority is positioned, in some exceptional circumstance, to directly coerce an individual or business to follow a specific law at a specific moment. In other words, adhering to any given law is wholly dependent on the immediate coercive power of the authorities.

We thus take a novel approach to the persistence of failure in these states by positing the absence of a particular social norm necessary for the rule of law to function as the formalists have assumed. That norminternalized at the level of the individual - is one in which those individuals adhere to their country's rule of law. In other words, while most analyses of the rule of law focus on the mere existence of normatively desirable rules, we focus on the individual's disposition to actually comply with such rules.

${ }^{11}$ D. Acemoglu, J. Robinson, Why Nations Fail: The Origins of Power, Prosperity, and Poverty, cit., p. 57, emphasis added.

12 See, i.e., J. Buchanan, The Limits of Liberty: Between Anarchy and Leviathan, in "The Collected Works of James M. Buchanan", vol. 7, Indianapolis, Liberty Fund, 1975; F. HAYEK, Law, Legislation and Liberty: Rules and Order (vol. 1), Chicago, University of Chicago Press, 1973; D. NorTH, Institutions, Institutional Change and Economic Performance, Cambridge, Cambridge University Press, 1990; T. M. TYLER, Why People Obey the Law, Princeton, Princeton University Press, 2006; C. BICCHIERI, The Grammar of Society: The Nature and Dynamics of Social Norms, New York, Cambridge University Press, 2006; E. Awad, S. Dsouza, R. Kim, J. Schultz, J. Heinrich, A. Shariff, J-F. Bonnefon, I. RAHAN. The Moral Machine Experiment, in "Nature", November, 2018, pp. 59-64. 
We operationalize this claim as a proclivity to comply with national laws ${ }^{13}$. Specifically, we argue that individuals in three key social groups in failed states - the nation's leadership, mid-level civil servants, and citizens/businesses - have not internalized a norm of adhering to national laws and standards in the way the overwhelming number of citizens do in thriving polities. As a result, individuals in all three groups not only defy national laws, they actually reinforce a social norm of noncompliance. Thus, when actors break laws, they introduce the very corruption, anemic growth, internal insecurity, and public incapacity that are hallmarks of failed states.

We support the claim that failed states lack a norm to follow national law, first, by reviewing a number of cross-country surveys and experiments that indicate prosocial norms are likely weaker in failed states. Second, we provide an analytic narrative, which constitutes the bulk of the paper, describing how and why individuals in each of the three groups regularly break national laws and thereby entrench or "lock-in" the norm that national law can be disregarded 14 .

A key feature of our approach is to show that noncompliance with national laws in the failed state environment gives rise to a persistence of that failure because of a prisoner's dilemma, of sorts: even if superior formal institutions could be established, individuals from the three societal groupings would lack the incentives to adhere to them without direct coercion, knowing the other groups have no incentive to adhere to them. The widespread disregard of national laws negatively impacts the likely emergence or evolution of an informal norm of complying with national laws because of the lived experience each individual has of breaking the law and seeing others around them, from virtually all socio-economic stations, break similar laws. The chances of an abrupt "system-wide" escape from this setting is thus highly improbable.

13 We readily acknowledge individuals routinely comply with sub-national, tribe, clan, and local rules, a topic we return to in greater detail in sections 3 and 4.

${ }^{14}$ We want to be clear that we do not claim that compliance with laws, in itself, provides the national authority with any morally or normatively superior standing. In other words, our assertion that broad compliance to established laws and institutions is critical to the political and economic development of these countries does not imply the rules or institutions of said countries are optimal, inherently good, just, or legitimate. 


\section{Which States are Failed?}

This section identifies those states that are failed. We base our list on the most unstable countries identified by either the Fund for Peace's Fragile State Index (FSI) or the World Bank's Harmonized List of Fragile Situations for five or more years ${ }^{15}$. These indices attempt to measure insecurity, which we argue is not a causal feature of state failure. However, because insecurity is an outcome of state failure, identifying those states that exhibit insecurity is equivalent to identifying those states that are failed.

We use both the FSI and the World Bank's Harmonized List because each organization has created a composite index based on a different set of factors and each methodology has strengths and weaknesses ${ }^{16}$. The differences in methodology result in slightly different lists of failed states. For example, the FSI includes the size of refugee flows, while the World Bank does not. Consequently, small island nations in the South Pacific, due both to their remote location and relatively small populations, cannot have large refugee flows sufficient for the FSI to rank them as failing, yet their other indicators are sufficiently poor for the World Bank to label many of these countries as failed. The World Bank index is, moreover, a political list with real-world consequences because foreign aid and peacekeeping decisions are often predicated on which countries the World Bank's list includes.

Table 1 lists the 47 countries that appear either in FsI's top 20 "fragile states" or in the World Bank's list for at least five years. This list of states comprises $15 \%$ of the world's population, meaning roughly 1.2 billon people live precariously in a nation characterized by a lack of growth, capricious state agents, and rampant internal insecurity.

15 Fund For Peace, The Fragile States Index. Available at: http://ffp.statesindex.org (last accessed 30 September 2018). See WORLD BANK data on the Harmonized List of Fragile Situations. Available at: http://www.worldbank.org/en/topic/fragilityconflictviolence/brief/ harmonized-list-of-fragile-situations (last accessed 29 August 2020).

16 The FSI has been published since 2006 and uses different social, political, and economic indicators to determine which states are or are not failed. Higher scores in the FSI are considered "fragile" states and we specifically assume that any country in the top 20 is "failed". The World Bank's Harmonized List of Fragile Situations, published since 2006, has a similar, though less transparent approach: it first calculates a state's capacity by reference to different social, political, and economic indicators, then lists a state as "fragile" so long as it has either a very low score on its capacity index or has a United Nations Peacekeeping mission operating within its territory. See World Bank data on the Harmonized List of Fragile Situations. 
Table 1 - List of Failed States (Alphabetical).

\begin{tabular}{|c|c|c|c|}
\hline 1 & Afghanistan & 25 & Mali \\
\hline 2 & Angola & 26 & Marshall Islands \\
\hline 3 & Burundi & 27 & Micronesia \\
\hline 4 & Cambodia & 28 & Myanmar \\
\hline 5 & Central African Republic (CAR) & 29 & Nepal \\
\hline 6 & Chad & 30 & Niger \\
\hline 7 & Comoros & 31 & Nigeria \\
\hline 8 & Congo, Dem. Rep. (DRC) & 32 & Pakistan \\
\hline 9 & Congo, Rep. & 33 & Papua New Guinea \\
\hline & Cote D'Ivoire & 34 & Sao Tome and Principe \\
\hline & Djibouti & 35 & Sierra Leone \\
\hline & Eritrea & 36 & Solomon Islands \\
\hline & Ethiopia & 37 & Somalia \\
\hline & Gambia & 38 & South Sudan \\
\hline & Guinea & 39 & Sudan \\
\hline & Guinea-Bissau & 40 & Syria \\
\hline & Haiti & 41 & Timor-Leste \\
\hline & Iraq & 42 & Togo \\
\hline & Kenya & 43 & Tonga \\
\hline & Kiribati & 44 & Tuvalu \\
\hline & Laos, PDR & 45 & Uzbekistan \\
\hline & Lebanon & 46 & Yemen \\
\hline & Liberia & 47 & Zimbabwe \\
\hline 24 & Madagascar & & \\
\hline
\end{tabular}

Source: The World BAnK, Doing Business, cit.; Fund for Peace, The Fragile States Index, cit..

Note: The following countries were in the top 20 of the FSI for five or more years, but not in the World Bank index for five or more years: Ethiopia, Kenya, Niger, Nigeria, and Pakistan.

\section{Social Norms and National Laws}

As noted in the introduction, when analysts focus on the role the rule of law plays, they overwhelmingly focus on formal properties and its "existence". In other words, has a given country established certain formal institutions that conform to a set of desirable normative properties (i.e., are the nation's rules legislatively established and equally applied)? We challenge such a view and instead posit that persistent 
state failure is a function of the predominance of informal social norms that discourage compliance with national law. While our claim rests on a growing literature that analyzes informal institutions, we cannot, of course, survey the entire field. We wish, instead, to convey the basic foundations of our approach, which begins with North: “... Formal rules, in even the most developed economy, make up a small... part of the sum of constraints that shape choices; a moment's reflection should suggest to us the pervasiveness of informal constraints.... That the informal constraints are important in themselves (and not simply as appendages to formal rules) can be observed from the evidence that the same formal rules and/or constitutions imposed on different societies produce different outcomes. ... [W] hat is most striking (although seldom observed, particularly by advocates of revolution) is the persistence of so many aspects of a society in spite of a total change in the [formal] rules" 17 .

Concerning the interplay between formal and informal rules, Yandle argues, it is highly misleading to view constitutions "as purely political instruments developed by wise and strong leaders and imposed on a loosely organized society. ... [A] "nation's constitution [is] ... rooted in the norms of individuals that form communities and states. Constitutions grow from within; they are not imposed from outside"18. In other words, as Hayek emphasizes decades earlier, lawin the general sense of following social rules - "is older than legislation"19. In our context, social norms are thus antecedent to formal laws and political structures that might solve state "incapacity" or "insecurity," a point that has particular relevance for those ob-

${ }^{17}$ D. NoRTH, Institutions, Institutional Change and Economic Performance, cit., pp. 36-37, emphasis added. On the issue of the generation or origin of social norms, North suggests, "They come from socially transmitted information and are part of the heritage that we call culture.... Culture provides a language-based conceptual framework for encoding and interpreting the information that the senses are presenting to the brain". See also F. HAYEK, Law, Legislation and Liberty: Rules and Order (vol. 1), cit. for the same point, with considerably greater detail.

${ }^{18}$ B. Yandle, Organic Constitutions and Common Law, in "Constitutional Political Economy", n. 2, 1991, p. 225, emphasis added.

${ }^{19}$ F. HAYEK, Law, Legislation and Liberty: Rules and Order (vol. 1), cit., p. 72. In fact, Hayek suggests that social rule-following probably predates the emergence of developed language, surely a necessary condition for the articulation of formal rules. See also B. LEONI, Freedom and Law, cit., , pp. 145-147 on this point. 
servers who have attempted to impose new or external formal structures upon failed states ${ }^{20}$.

Buchanan emphasizes that modern societies require informal norms to reduce potential conflict and, thus, increase social stability and predictability: "Observed orderly behavior depends critically on mutual acceptance of certain informal precepts by all parties" 21 . Informal norms, moreover, have important advantages over formal institutions because the enforcement costs - and impingement on liberty - of informal norms will be lower: "Life in society, as we know it, would probably be intolerable if formal rules should be required for each and every area where interpersonal conflict might arise. ... An indirect test of the cohesiveness of a society may be offered in the range of activities that are left open to informal rather than formal control'22. Leoni's magnum opus similarly develops a wide-ranging critique of what he calls the "notion of legislation as a panacea"23.

Buchanan also provides a microeconomic analysis of individual adherence to informal norms - and law in general - in his aptly-named chapter, "Law as Public Capital"24. In it, he applies familiar publicgoods/free-rider analysis to the incentives to obey the law: the "public" aspect of the chapter title emphasizes the fact that adhering to a law provides a pure external economy from the perspective of the individ-

20 This point is, incidentally, broadly consistent with Easterly's thesis that is highly critical of the long tradition of western "experts" who have attempted to impose various development paradigms on the impoverished world with woefully little to show in terms of success: W. EASTERLY, The Tyranny of Experts: Economists, Dictators, and the Forgotten Rights of the Poor, New York, Basic Books, 2014.

21 J. BuCHANAN, The Limits of Liberty: Between Anarchy and Leviathan, cit., p. 117, emphasis added.

22 J. Buchanan, The Limits of Liberty: Between Anarchy and Leviathan, cit., p. 118, emphasis added.

${ }^{23}$ B. LEONI, Freedom and Law, cit., p. 5. Consider, for example, Leoni's inversion of the commonly-held argument for laws over (the idiosyncrasies of) men: "The paradoxical situation of our times is that we are governed by men, not, as the classical Aristotelian theory would contend, because we are not governed by laws, but because we are. In this situation it would be of very little use to invoke the law against such men. Machiavelli himself would not have been able to contrive a more ingenious device to dignify the will of a tyrant who pretends to be a simple official acting within the framework of a perfectly legal system". See B. LeONI, Freedom and Law, cit., p. 9.

24 J. Buchanan, The Limits of Liberty: Between Anarchy and Leviathan, cit., pp. 107-129. 
ual; it is all cost and no (direct) benefit to the observant citizen. Yet, individuals do frequently obey the law because they have internalized a norm that comprehends that others also follow the law, thereby increasing social stability. The maintenance of individual adherence is constantly threatened, however, when "... a critically large minority of persons... are observed to violate ethical precepts that previously have been accepted by almost everyone, and to act on self-interest grounds... [T] hose who might continue to adhere to the precepts find themselves subjected to what may seem to be exploitation" 25.

The "capital" element of the chapter title emphasizes that norms must be understood in a historical, dynamic framework, in the way that we understand capital formation: the fact that some societies have stabilizing social norms today is the result of past efforts (viz. "investments") on the part of previous generations. This capital formation view of social norms suggests an important asymmetry: it will likely take longer - and require considerably more effort — to build a stable, prosperous community, which depends on this unseen social capital, than it will be to destroy it. In Buchanan's own words: "Once a critical limit is passed here, the standards may erode rapidly as more and more individuals revert to narrowly defined self-interest. ... This suggests that one of the most important ethical precepts may well be that of obedience to and respect for formalized law, ... [Such an] attitude may, in fact, explain much of the order that we observe, an order that exists even in those aspects of behavior when most persons recognize that enforcement of formal rules is nonexistent or woefully inadequate" 26 .

In sum, formal rule structures can never fully account for the prosperity and stability observed in developed, largely peaceful societies and the informal norms that support the formal rules are highly fragile in the sense that they are both difficult to establish — probably taking generations - and easy to destroy.

Unfortunately, good cross-country measures of compliance with the law do not exist even though there is readily observable data on,

25 J. BuCHANAn, The Limits of Liberty: Between Anarchy and Leviathan, cit., pp. 118119, emphasis added.

26 J. Buchanan, The Limits of Liberty: Between Anarchy and Leviathan, cit., pp. 117119, emphasis added. See also F. HAYEK, Law, Legislation and Liberty: Rules and Order (vol. 1), cit., p. 72 for a similar argument. 
for example, the size of prison populations, the number of convictions, compliance with tax law, and the like. The latter are not particularly helpful to our argument because they bear more directly on the particulars of a criminal justice or tax system within a country and not on the question of whether people follow the law more generally ${ }^{27}$.

There is nevertheless evidence consistent with our claim. Specifically, data from various surveys reveal that trust tends to be lower in failed states, and citizens in failed states seem to feel less comfortable with the police enforcing the law. Additionally, behavioral results show that individuals in small-scale societies that are similar to tribes and clans within failed states exhibit substantially less pro-social behavior. We buttress this evidence with anecdotes from within failed states that describe the regularity with which national laws are flouted.

Before discussing the first set of evidence, survey data on "trust", we want to define trust and establish the link between it and our claim of noncompliance with national-level laws. Trust is routinely defined as a belief in the reliability, truth, ability, or strength of someone, and therefore is clearly tied to an expectation of reciprocity. As Bicchieri points out, social rules of all sorts, including formal and informal ones, depend on whether norms are actually followed in the community and on an expectation that norms will be generally followed by others in the community ${ }^{28}$. The failure of either condition will weaken such a norm.

Our reliance on the concept of trust is tied to a more substantial literature that distinguishes between "generalized" and "particularized" trust. Generalized trust refers to an environment in which most people, including strangers, can be trusted, while particularized trust-most readily represented by family ties - is characterized by fewer but stronger connections. The important distinction between the two is that particularized trust does not equip citizens to overcome wider social collective action problems. Generalized trust, on the other hand, means " participation in the larger society ... [which] helps to build the bridges

${ }^{27}$ Near the end of the paper, we provide several examples of laws that are self-evidently ignored by the vast majority of citizens within particular countries. An exhaustive study of the set of laws not followed within a particular failed state or across failed states is, of course, outside the scope of this paper.

${ }^{28}$ C. BICCHIERI, The Grammar of Society: The Nature and Dynamics of Social Norms, cit.. See also J. Buchanan, The Limits of Liberty: Between Anarchy and Leviathan, cit.. 
across groups that are essential to solving collective-action problems. Whether people participate in [wider social associations] ... depends on how they relate to strangers and to their social milieu. If people are wary of strangers and stick to their own group in daily life, they are less likely to partake of the forms of collective action that build social capital. So civic engagement starts from the ground up with people's attitudes toward others and how they relate to them in daily life" 29.

Corruption, unsurprisingly, has been connected to lower levels of trust. For example, Banerjee's experimental evidence reveals what he calls "negative spillovers" of corruption on trust. Similar to Bicchieri, he emphasizes that the violation of a social appropriateness norm erodes trust specifically through its "adverse effect on belief about trustworthiness" 30 . He furthermore conjectures that "repeated interactions in a corrupt environment may lead to a behavioral stationary state of low trust" 31 . In other words, trust — or the belief that others will act in good faith - directly affects both the perception and level of lawfulness in the community. Without trust in others, including anonymous others, an individual would not expect "the community" to comply with the law. These beliefs are, moreover, self-fulfilling: individuals are encouraged to break the law if they perceive it as normal to do so.

Trust does indeed appear to be lower in failed states as measured by the World Values Survey (wVs). The survey asks whether most people should be trusted or whether one needs to be "very careful" 32 . While

${ }^{29}$ E. Uslaner, R. Conley, Civic Engagement and Particularized Trust: The Ties that Bind People to their Ethnic Communities, in "American Politics Research", n. 4, 2003, p. 334.

${ }^{30}$ R. BANERJEE, Corruption, Norm Violation and Decay in Social Capital, in "Journal of Public Economics", Vol. 137, 2016, p. 14, emphasis added.

${ }^{31}$ R. BANERJeE, Corruption, Norm Violation and Decay in Social Capital, cit., p. 25. For a formal, evolutionary model showing how interactive behavior among individuals who comply with one type of norm, or its opposite, depends on the degree to which others in the community are following the norm, see K. JAKEE, G. SUN, External Habit Formation and Dependency in the Welfare State, in "European Journal of Political Economy", Vol. 21, 2005, pp. 83-98.

32 R. Inglehart, C. Haerpfer, A. Moreno, C. Welzel, K. Kizilova, J. Diez-Medrano, M. Lagos, P. Norris, E. Ponarin, B. Puranen (eds.), World Values Survey: All Rounds Country-Pooled Datafile Version, 2014. Available at: http://www.worldvaluessurvey. org/WVSDocumentationWVL.jsp (last accessed: August 2020). Johnson and Mislin use a unique data set of trust game replications to validate the trust question in World Values Survey. See N. D. Johnson, A. Mislin, How Much Should We Trust the World Values Survey Trust Question? in "Economic Letters", n. 2, August, 2012, pp. 210-212. 
only nine of the 47 failed states have ever appeared in the Wvs, six of these nine have values of trust below the mean in all years surveyed, one (Pakistan) has levels of trust below the mean in two out of three years surveyed, and just two countries (Yemen and Iraq) have levels of trust above the mean in all years surveyed. These nine, their responses to the trust question, and the average level of trust in that round are displayed in Table 2 .

Table 2 - Trust in Failed States.

\begin{tabular}{|c|c|c|c|c|}
\hline Country & WVS Round & Percent who Trust & Mean Trust & Number of Countries \\
\hline Ethiopia & $2005-2009$ & 21.4 & 25.8 & 57 \\
\hline Haiti & $2010-2014$ & 21.3 & 23.0 & 60 \\
\hline Iraq & $2010-2014$ & 30 & 23.0 & 60 \\
\hline Iraq & $2005-2009$ & 38.6 & 25.8 & 57 \\
\hline Iraq & $2000-2004$ & 46.1 & 26.3 & 41 \\
\hline Lebanon & $2010-2014$ & 9.8 & 23.0 & 60 \\
\hline Nigeria & $2010-2014$ & 15 & 23.0 & 60 \\
\hline Nigeria & $2000-2004$ & 25.3 & 26.3 & 41 \\
\hline Nigeria & 1995-1999 & 16.4 & 24.9 & 55 \\
\hline Pakistan & $2010-2014$ & 22.2 & 23.0 & 60 \\
\hline Pakistan & $2000-2004$ & 28.2 & 26.3 & 41 \\
\hline Pakistan & 1995-1999 & 20.4 & 24.9 & 55 \\
\hline Uzbekistan & $2010-2014$ & 13.9 & 23.0 & 60 \\
\hline Yemen & $2010-2014$ & 38.5 & 23.0 & 60 \\
\hline Zimbabwe & $2010-2014$ & 8.3 & 23.0 & 60 \\
\hline Zimbabwe & $2000-2004$ & 11.7 & 26.3 & 41 \\
\hline \multicolumn{5}{|c|}{$\begin{array}{l}\text { Source: R. Inglehart, C. Haerpfer, A. Moreno, C. Welzel, K. Kizilova, J. Diez- } \\
\text { Medrano, M. Lagos, P. Norris, E. Ponarin, B. PURAnen (eds.), World Values Survey: } \\
\text { All Rounds - Country-Pooled Datafile Version, cit.. } \\
\text { Note: Bolded numbers are below the mean. }\end{array}$} \\
\hline
\end{tabular}

A high level of measured trust does not, itself, guarantee that national laws will be respected. For example, one of the failed state exceptions in the trust study, Yemen, has high levels of measured trust, despite highly chaotic domestic politics. As of this writing, Yemen remains embroiled in a multisided civil war, but even before this civil war began in 2011, politics were far from regularized and rule-abiding was low. Tribal groups routinely ignored and broke national laws for potential gain, kidnapped foreigners, and attacked oil company assets 
and personnel to extract privileges from the central government 33 . Tribes collected their own taxes and protection money, and sheikhs in Sanna received large commissions "for acting as a local agent" despite not being involved with any of the local tribes ${ }^{34}$. In other words, national laws were not relevant to day-to-day actions, but tribes and sheiks were. We therefore cannot explain the apparent inconsistency of high levels of trust in the survey of Yemen where sub-national tribal groups have dictated socio-political dynamics. One possibility is that the data, itself, is unreliable 35 .

The second area of evidence connecting social norms to nationallevel compliance focuses on the willingness to punish defectors: for a norm to exist, deviators must be punished either by other individuals or the state ${ }^{36}$. In Round Six of the Afrobarometer, the survey asked whether individuals agreed with the statement, "The police always have the right to make people obey the law" 37 . This question should not be interpreted as a direct question of whether individuals should obey the law, but whether the police-who are normally assumed to have the authority to enforce the law-should actually do so.

There do seem to be differences in responses based on whether the state is failed. Fourteen of the 36 African countries surveyed in Afrobarometer are failed states. Citizens either disagreed or strongly disagreed with the statement at a rate greater than the median (14.4\%) in 10 of the 14 failed states ${ }^{38}$. While the evidence we present does admit

33 V. CLARK, Yemen: Dancing on the Heads of Snakes, New Haven, Yale University Press, 2010, p. 184.

34 V. Clark, Yemen: Dancing on the Heads of Snakes, cit., p. 184.

35 See K. NuR-TEgin, K. JAKEE, Does Corruption Grease or Sand the Wheels of Development? New Results Based on Disaggregated Data, in "Quarterly Review of Economics and Finance", February, 2019, pp. 19-30 for a discussion of the data and reliability problems inherent in a number of surveys, such as the wvs.

${ }^{36}$ On the matter of enforcement, see Chapter 8 in J. BuchanAn, The Limits of Liberty: Between Anarchy and Leviathan, cit., on "the punishment dilemma". Or, see Chapter 7 in D. NorTH, Institutions, Institutional Change and Economic Performance, cit., which is dedicated to enforcement.

${ }^{37}$ Afrobarometer Round Six, 2017. Available at : www.afrobarometer.org (last accessed: 30 September 2020).

${ }^{38}$ Specifically, citizens disagreed with the statement at the following rates: Burundi (15.8\%), Cote d'Ivoire (25.5\%), Guinea (18.7\%), Kenya (20.1\%), Liberia (18.4\%), Madagascar (19.4\%), Mozambique (23.6\%), Nigeria (23.6\%), Sao Tome and Principe (25.1\%), and Togo $(35.3 \%)$ disagreed or strongly disagreed at rates greater than the median. Sudan 
several ambiguities, $71 \%$ of the failed states disagreed that the police have the right to make people obey the law at a rate above the median of all countries. Most striking, in three of the 14 countries (e.g., Cote d'Ivoire, Sao Tome and Principe, and Togo), more than one quarter of those surveyed disagreed that police should play such a role, meaning one out of four citizens believes the police should not enforce the law.

What does the lack of such a belief mean in practice? Consider the case of Alhaji Dahiru Mangal, a smuggling lord in Nigeria. In 2005, when Nigeria's Obasanjo regime attempted to curtail Mangal's illicit operations $^{39}$, Mangal is quoted as asking Obasanjo's representatives, "Why does Obasanjo call me a smuggler? I just do logistics. ... I'm just providing a service" 40 . Apparently for Mangal, the law was merely an obstacle, a cost of transacting that he routinely paid politicians to overcome; the surmounting of these obstacles was, presumably, part of his market "service" 41.

The third area of evidence comes from the low levels of measured pro-social behavior in small-scale societies. While the above data used surveys to measure trust and the belief that police should enforce the law, pro-social behavior can be measured through deviations from predicted self-interested behavior in cooperative games; this evidence tends to be experimental or quasi-experimental. If generalized pro-social behavior was lower in failed states, then individuals would behave more selfishly, cooperate less, punish rule breakers less, and exhibit behaviors that are consistent with lower trust societies ${ }^{42}$. As such, individuals in these societies are highly unlikely to have internalized a norm of following broad, national laws.

Indeed, it appears that such pro-social behavior is lower in small-

disagreed at precisely the median rate, while Niger (9.6\%), Sierra Leone (7.8\%), and Zimbabwe $(8.6 \%)$ disagreed at rates below the median.

${ }^{39}$ T. Burgis, The Looting Machine: Warlords, Oligarchs, Corporations, Smugglers, and the Theft of Africa's Wealth, New York, Public Affairs, 2015, p. 68.

${ }^{40}$ T. Burgis, The Looting Machine: Warlords, Oligarchs, Corporations, Smugglers, and the Theft of Africa's Wealth, cit., pp. 68-69.

${ }^{41}$ T. BuRgIs, The Looting Machine: Warlords, Oligarchs, Corporations, Smugglers, and the Theft of Africa's Wealth, cit., p. 68.

42 Johnson and Mislin argue that the trust question in the World Values Survey and these types of experimental games are measuring the same thing. See N. D. Johnson, A. Mislin, How Much Should We Trust the World Values Survey Trust Question?, cit., pp. 210-212. 
scale societies. Henrich et al. documents global variation in pro-social behavioral traits most frequently observed in western, educated, industrialized, rich, and democratic societies, which the authors refer to as "WEIRD" societies ${ }^{43}$. The authors specifically investigate whether there are important similarities or differences between WEIRD and small-scale societies ${ }^{44}$. Their results indicate that, in 23 small-scale societies, individuals played fairness and cooperation-centric economic games, such as Ultimatum and Dictator games, very differently than individuals from WEIRD societies. Specifically, individuals played less cooperatively, offered lower values, and punished unfair behavior less frequently in small-scale societies as compared to WEIRD societies. Without individually-supplied cooperation or punishment, national laws are unlikely to function well because formal authority (the police and other official enforcement mechanisms) will never be able to fully seek out and punish defectors.

For our purposes, sub-groups or tribes within a nation state are analogous to small-scale societies in Henrich et al.'s study ${ }^{45}$. And, while some might argue Henrich et al.'s study cannot be taken as evidence of conditions in failed states, generally - because, for example, some of their small-scale societies inhabited states not on our list of failed states - our point is merely that their analysis is consistent with the direction that we would expect if such a norm was absent in failed states $^{46}$. Further, small-scale societies in non-failed states look remarkably similar to the small-scale societies in failed states.

In sum, survey data seems to indicate that failed states exhibit lower levels of trust and lower levels of belief that police should enforce the law. Comparisons between small-scale societies, of which failed states

43 J. Henrich, S. J. Heine, A. Norenzayan, The Weirdest People in the World? in "Behavioral and Brain Sciences", n. 2/3, 2010, pp. 61-83.

${ }^{44}$ Small-scale societies are usually sub-state tribes or clans in impoverished countries where researchers conducted experimental games to measure their level of pro-social behavior.

45 J. Henrich, S. J. Heine, A. Norenzayan, The Weirdest People in the World?, cit. pp. 61-83.

46 There was, however, a number of countries on the Heinrich et al. list that overlap with our list of failed states, notably Kenya, Papua New Guinea, and Zimbabwe. Another criticism might be that these samples come from only 15 small-scale societies, while many (failed) states encompass hundreds or more of subunits like these. 
are normally composed, and WEIRD ones also show lower levels of cooperative behavior and punishment by individuals in small-scale societies. Each of these findings support our contention that failed states lack norms of compliance with national laws. Clearly, these results are tentative and further research along these lines would help clarify these empirical connections.

\section{National Laws and Key Socioeconomic Groups: Incentives and Dynamics}

This section turns to the incentive structure facing three classes of actors in failed states - the political leadership, civil servants, and individual citizens/businesses - and the dynamics of this incentive structure. We build an analytic narrative that examines motives, constraints, and strategies to show that, as these individuals interact, their actions all contribute to the entrenchment of national lawbreaking as a social norm.

\subsection{The Leader and Top Ministers}

The leader is the head of state and, in theory, directs the country ${ }^{47}$. In failed states, the leader is invariably an autocrat or dictator. We argue that, in an effort to prolong their reign, leaders in failed states frequently break or change national laws to suit their own, fleeting interests. As the leader breaks and changes national law for his own ends, he provides a powerful example to others that national law may be broken for individual ends, thereby making national law more arbitrary and difficult to follow. These often-transparent behaviors of leaders discourage a norm of national compliance as evidenced by interviews of multiple business owners in Nigeria concerning their lack of tax compliance ${ }^{48}$. Umar et al. refer to this tax resistance as a "tax boycott-a

47 While the leadership of a country could be a cartel (like a military junta), for our purposes we assume a cartel functions as a unitary actor to simplify the analysis.

${ }^{48}$ M. Umar, C. Derashid, I. Ibrahim, What Is Wrong with the Fiscal Social Contract of Taxation in Developing Countries? A Dialogue with Self-Employed Business Owners in Nigeria, in "Sage Open", October-December, 2017, pp. 1-11. 
deliberate abandonment of tax obligations due to dissatisfaction with governance" 49 . As one participant noted, "those in government are there for their own selfish interest hence [they] do not 'carry citizens along' in affairs of governance. ... They are like a cult, when you find yourself in government, you take your share but when you are an ordinary citizen like me, you are on your own - how do you pay tax to people who are so rich from government money? ... [On the matter of political representation, she replied] ... How do they represent me? They only represent their pockets and those of their families and friends" 50 .

Additionally, because a dictator only secures the benefits of dictatorship by retaining power, most of his actions are designed to retain power. There are two broad avenues by which leaders lose their position: coups and revolutions. To limit the likelihood of revolution, dictators frequently create multiple cleavages dividing society and potential opposition groups ${ }^{51}$. One way cleavages can be created is by manipulating national laws. Leaders of failed states have been known to change laws with the precise intent of making compliance with such laws a signal of support for the regime. Breaking national laws in this scenario can thus be a signal of a rival anti-regime faction and not lawlessness, per se. When breaking national law is a sign of sub-group affiliation, national law, by definition, is no longer commonly shared or applied.

For example, in discussing the roots of the conflict in Darfur, Cockett reports the People's Local Government Act of 1971 intentionally divided tribes into separate political units ${ }^{52}$. Then, in 1989, Darfur was divided into three separate states ensuring the non-Arab Fur, which was the majority ethnic group in Darfur, would no longer be a majority in any of the three new provinces. The government also provided weapons

${ }^{49}$ M. Umar, C. Derashid, I. IBrahim, What Is Wrong with the Fiscal Social Contract of Taxation in Developing Countries? A Dialogue with Self-Employed Business Owners in Nigeria, cit., p. 2.

${ }^{50}$ M. Umar, C. Derashid, I. Ibrahim, What Is Wrong with the Fiscal Social Contract of Taxation in Developing Countries? A Dialogue with Self-Employed Business Owners in Nigeria, cit., p. 5.

${ }^{51}$ D. Acemoglu, J. A. Robinson, T. Verdier, Kleptocracy and Divide-and-Rule: A Model of Personal Rule, The Alfred Marshall Lecture, in "Journal of the European Economic Association Papers and Proceedings", April-May, 2004, pp. 162-92.

52 R. CocketT, Sudan: Darfur and the Failure of an African State, New Haven, Yale University Press, 2010, p. 171. 
to Arab herders and pastoralists and permitted them to raid the villages of the non-Arab Fur. As one Justice and Equality Movement commander put it, "'The government is giving arms and weapons to the Arab tribes only. We asked for protection from the government but unfortunately they did not give the same weapons to us" ${ }^{53}$.

Thus, at first, the government imposed legal changes to disadvantage the Fur, and these made the national law less reliable from the perspective of the Fur. Later, the government permitted the Janjaweed (Arab militias) to break national laws against murder and raiding because these violations benefited the regime. As the Darfuris could not rely on national law to proscribe rules for orderly behavior, they began to attack government installations and the other Arab tribes in 2003. Because the Fur remain divided and other surrounding ethnic groups support the regime, the conflict has not grown large enough to threaten the state. The nature of the Darfuri conflict has also ensured that any protection that might be provided by national law is not enjoyed equally across the different communities in Sudan.

Since dictators must also resist coups to stay in office, they must be able to entice the support of other elites and ministers and/or repress opponent elites and ministers ${ }^{54}$. Indeed, dictators will fear that today's supportive ministers might participate in a coup tomorrow, so the selection of ministers must be done carefully. Specifically, dictators are only likely to appoint ministers if: (1) the leader's support depends on the manager to some extent, or (2) the leader trusts the minister ${ }^{55}$. These criteria are, moreover, unlikely to favor individuals who follow the law.

One reason such ministers are unlikely to follow the law is because they are ignorant of what the ministry is actually meant to do or how to run a ministry. Tullock, Brough and Kimenyi, and Egorov and Sonin

${ }^{53}$ R. Cockett, Sudan: Darfur and the Failure of an African State, cit., p. 171. The Justice and Equality Movement is a mostly non-Arab Sudanese opposition and rebel group based in Darfur that has been fighting the government since 2001.

${ }^{54}$ G. Tullock, The Social Dilemma: The Economics of War and Revolution, Fairfax, Center for the Study of Public Choice, 1974; G. Tullock, Autocracy, Dordrecht, Martinus Nijhoff Publishers, 1987; R. WINTROBE, The Political Economy of Dictatorship, New York, Cambridge University Press, 1998.

55 G. TulLock, Industrial Organization and Rent Seeking in Dictatorships, in C. RowLEY (ed.), "The Selected Works of Gordon Tullock: Vol. 5. The Rent-Seeking Society", Indianapolis, Liberty Fund, 2005[1986], p. 127. 
argue those given a position in return for political support are unlikely to be as skilled as those who would be selected through a competitive, meritorious hiring process ${ }^{56}$. They routinely lack the education, experience, and ethical principles that would produce efficient, rule-bound management; bureaus will therefore be more chaotic.

A second reason ministers will not be bound by laws is these government positions often exist specifically for fostering public corruption, not for enforcing laws. Girard clearly illustrates, for example, how one Haitian leader fought vigorously against more efficient management ${ }^{57}$. In 1996-1997, there was an attempt to privatize a number of Haitian state-owned enterprises ${ }^{58}$. Jean-Bertrand Aristide was, at the time, the ex-president of Haiti, but still leader of the largest political party: he thus continued to wield considerable power. He was strongly opposed to privatization of state-owned enterprises because they afforded many coveted posts with relatively high pay and minimal work, effectively operating as spoils for his supporters. Reform of these parastatals and the selection of better managers would have meant less public corruption and reduced tolerance for national law-breaking. Thus, while such reforms were likely to have improved economic conditions in Haiti, the loss of these lucrative positions was too risky for those who controlled them ${ }^{59}$.

While the selection process will affect the relative efficiency of a given minister's ability to deliver goods and services, the very reason for that minister's selection - to keep the dictator in power-has profound effects on the ability to constrain that minister. The minister does not only serve at the leisure of the president, but the president also serves at the leisure of the ministers, as each minister is a potential coup

${ }^{56}$ G. Tullock, Industrial Organization and Rent Seeking in Dictatorships, cit., p. 127; W. Brough, M. KimenYI, On the Inefficient Extraction of Rents by Dictators, in "Public Choice", n. 1, 1986, pp. 37-48; G. Egorov, K. SonIn, Dictators and Their Viziers: Endogenizing the Loyalty-Competence Tradeoff, in "Journal of European Economic Association", n. 5, 2011, pp. 903-930.

57 P. GIRARD, Haiti: The Tumultuous History. From Pearl of the Caribbean to Broken Nation, New York, Palgrave Macmillian, 2010, pp. 178-179.

58 P. GIRARD, Haiti: The Tumultuous History. From Pearl of the Caribbean to Broken Nation, cit., pp. 178-179.

${ }^{59}$ P. GIRARD, Haiti: The Tumultuous History. From Pearl of the Caribbean to Broken Nation, cit., p. 179. 
leader or coup supporter. And because the leader will want to limit the ministers' incentives to create or join future attempted coups, the former will be concerned about the constraints he imposes on the latter. This concern is driven by the fact that the more constraints a sovereign places on his ministers, the greater the likelihood his ministers become dissatisfied and consider supporting potential coups. The leader is thus unlikely to closely monitor whether any trusted minister is following national laws, unless the actions, like treachery, directly threaten the leader. The result is a largely unconstrained bureaucracy, as Haber has described ${ }^{60}$.

For example, in the DRC, the government has been unwilling to limit corruption. According to the Congo Research Group, "It is clear that members of the elite on all sides of the political divides have abused their office for personal enrichment. While most international interventions in the Congo have placed an emphasis on negotiation and political compromise, they have failed to hold elites or the corporations they work with accountable for this kind of corruption" ${ }^{61}$. In other words, elites in Congo are often left unconstrained in their pursuit of economic enrichment or political support. The problem, of course, is that by leaving elites unconstrained, they are free to break national law as they pursue corrupt ends.

Finally, leaders will break the law in support of growing their own personal wealth. For example, Congo's Ministry of Mines issued more mining permits than would normally be allowed under the mining code to a company controlled by the president's sister, Janynet Kabila62. Stories like these are too common to enumerate in failed states and one critical effect is the president openly defies his own national law because it is either profitable or serves to keep him in power. The rest of the country-including other officials, citizens and business ownerstake this high-level disregard for the rules as a strong signal that rules are not meant to be followed or enforced, starting at the top. In sum,

${ }^{60}$ S. Haber, Authoritarian Government, in B. R. Weingast, D. WittMan (eds.), "The Oxford Handbook of Political Economy", New York, Oxford University Press, 2008, p. 696.

${ }^{61}$ See All the President's Wealth: The Kabila Business Family, in "Congo Research Group", 2017, p. 2. Available at: https://allthewealth.congoresearchgroup.org/dist/assets/ all-the-presidents-wealth-ENG.pdf (last accessed: July 2019).

${ }^{62}$ See All the President's Wealth: The Kabila Business Family, cit., p. 2. 
the leader and his ministers will repeatedly break national law or encourage national law to be broken. The leader divides society by sparking conflict, hires corrupt ministers that he cannot control, and is corrupt himself.

\subsection{Civil Servants}

While leaders and ministers have a powerful impact on the overall structure of national laws and on those at the top of the regime, there are layers of civil servants who will never come into direct contact with the leader or even the ministers. These lower- and mid-level bureaucrats are charged with enforcing national laws. We argue in this subsection that the institutional structure of failed states incentivizes these administrators to be corrupt and break laws, which, combined with the behavior of the leader and other top ministers, contributes to the common disregard of national laws in these systems.

Most assume the mission of a bureaucracy is synonymous with its title: the ministry of education educates, the ministry of the environment oversees environmental resources, and so on. But, in the failedstate environment, too often the ministry of the environment does not protect the environment and the ministry of education does not educate. By and large ministers and higher officials were not chosen to further these missions, as we discussed in the previous section. Instead, they were chosen to support the regime.

Ministers and higher officials will then select subordinate government officials for the support the latter can offer to the former. Thus, just as the leader is afraid ministers might support a coup, so will ministers fear their own subordinates might replace them; and, just as the leader permits ministers to be largely unconstrained in their actions, a minister's subordinates are similarly allowed to pursue their own ends as long as they do not result in disloyalty against the higher-level official. National law-following in bureaucracies therefore faces an "infinite regress" problem: as the ministers are permitted to regularly break the law, so too will those underneath them ${ }^{63}$.

${ }^{63}$ G. Tullock, Corruption and Anarchy, in C. Rowley (ed.), “The Selected Works 
But the incentives are typically even worse than this: civil servants in failed states are not merely permitted to break the law, they are encouraged to break the law in order to survive because they are notoriously underpaid. For example, a police officer in Sierra Leone makes only $\$ 58$ dollars per month, while a sack of rice-which typically feeds five people in the household - costs $70 \%$ of his monthly salary ${ }^{64}$. Facing such paltry salaries, these government officials frequently supplement their income through corrupt activities. One example is Central African Republic judges who decide cases based on who is willing to pay the highest fine ${ }^{65}$. Or, consider the case of the Congolese president who sent police and military to quell a rebellion in the Bas-Congo region in 2009: soldiers reportedly stole televisions, tables, and handbags in the course of carrying out their duties ${ }^{66}$.

There is, however, a more insidious process at work than mere larceny as in these two examples above: civil servants actually target those citizens who can be most easily extorted ${ }^{67}$. And these extortion attempts are not merely "one off" events, but often become ongoing costs (or penalties) on citizens. One reason these are recurring costs is that paying off a single official does nothing to quell extraction attempts by other officials. A different official might identify the same business

of Gordon Tullock: Vol. 1. Virginia Political Economy", Indianapolis, Liberty Fund, 2005, p. 326. An astute referee noted that we cannot rule out the possibility that some ministers or higher officials might be selected on meritorious grounds, a point with which we agree. However, it is precisely the dynamics we describe here that suggest even competent and well-meaning ministers will be corrupted by the system. If a minister's subordinates were able to provide better support to the leadership, then we predict that subordinate will replace his or her superior. As such, ministers must placate their own subordinates in order to retain their positions.

${ }^{64}$ R. DownIE, Building Police Institutions in Fragile States: Case Studies from Africa, in "A Report of the CSIS Africa Program", Washington, Center for Strategic and International Studies, 2013, p. 12. Available at: https://csisprod.s3.amazonaws.com/s3fspublic/ legacy_files/files/publication/130115_Downie_BuildPoliceInstitutions_web.pdf (last accessed: July 2019).

${ }^{65}$ R. MARCHAL, Being Rich, Being Poor: Wealth and Fear in the Central African Republic, in T. CARAYANnIS, L. Lombard (eds.), "Making Sense of the Central African Republic", New York, Zed Books, 2015, pp. 172-173.

${ }^{66}$ M. DeIBERT, The Democratic Republic of Congo: Between Hope and Despair, New York, Zed Books, 2013, pp. 172-173.

${ }^{67}$ F. MCCHESNEY, Rent Extraction and Rent Creation in the Economic Theory of Regulation, in "The Journal of Legal Studies", n. 1, 1987, pp. 112-117. 
owner and charge her for some infraction or purported government "service." In other words, each government agent often acts as a kind of tollbooth that charges those citizens who can be identified ${ }^{68}$.

An example comes from the exodus of Haitians in the early 1990s, when many tried to escape to the United States by boat. A photographer, Patrick Chauvel, documented the voyage of these "boat people" as recounted in Girard ${ }^{6}$. Before paying the captain for transport from Haiti, the refugees paid multiple local strongmen as well as police. If the voyage was forced back ashore - as many were - the passengers were compelled to hide from police and other agents who routinely looked for additional bribes.

Another example comes from a copper mine in the DRC where one of the present authors has direct experience. The mining company assisted the government in resettling a demobilized military group that had resided on its concession since the end of the Congolese Civil War. The group was to be relocated to their homes in other parts of the DRC. At one point, two military officers arrived to "supervise" the resettlement of a town, even though the actual resettlement process was to be carried out entirely by the mining company. While inspecting the town, the senior military officer noticed a house-sized water tank and asked mining personnel if he could have it. Per the negotiated mining code in Congo, the mining company owned all property within the concession, which included the water tank. The officer was reminded of the law and the agreement, which prompted him to demand a meeting with higher-level mining executives, who continued to refuse his efforts.

This incident demonstrates that, for the Congolese officer, the law was merely a starting point for negotiations and potential extraction, not a specification of rights or claims to be enforced by the state. While the mining company was, in the end, able to rebuff his attempts to expropriate the water tank because of prior contracts negotiated with an international conglomerate, the official still wasted a large amount of staff time with a request that, on its face, was absurd 70 .

68 See, for example, S. Djankov, R. La Porta, F. Lopez-De-Silances, A. Shleifer, The Regulation of Entry, in "Quarterly Journal of Economics", n. 1, 2002, pp. 1-37.

${ }^{69}$ P. GIRARD, Haiti: The Tumultuous History. From Pearl of the Caribbean to Broken Nation, cit..

${ }^{70}$ Curiously, the official had no means to transport the massive tank and made no 
Generalizing these dynamics suggests business owners will face myriad government officials claiming violations or the necessity of permits. Because both the agency and the legal system is corrupt, the veracity of the agent's claim is irrelevant. The real threat to citizens and businesses is of future interference, wasted time, and expropriated resources. The official need not even claim a regulation has been violated directly but may simply ask for a payment for some (often unclear) governmental service. We turn, again, to the Umar et al. interviews with Nigerian business owners for an example: "I do not receive any audit visit in my office except towards year end festivities and when the auditors come, they request ... chickens for Christmas and New Year celebrations" 71 . The citizen knows what this payment is for: to stop the state official from interfering in her life.

The citizen is unable to legally defend herself against agents of the state in these interactions because national laws protecting citizens against the state are neither observed nor enforced. No one-including civil servants, higher officials, prosecutors, or courts - will protect citizens or businesses unless the citizen/business is influential enough to be able to offer something of value for reducing official harassment. Our mining company example in DRC is a case in point: they had substantive, enforceable "rights" because of the amount of revenue they provided to the senior-levels of the regime.

Furthermore, while we would predict that government officials are less likely to extort their own group, tribe, or clan — as such predations are likely prevented by local norms and local tribal rules - they are more likely to extract resources from individuals perceived as outside their group or unprotected by such local rules. In an important asymmetry, bureaucrats, as agents of the national government, have regular access to multitudes of individuals who are not of their tribe or clan.

suggestion he would purchase it. Presumably, he hoped the mining company would simply give him the tank. Some days later, the officer's jeep was filled with hundreds of pounds of grain acquired in town. Observers assumed he had employed the same tactic of merely asking for the grain from some small farmer or shopkeeper. And, in all likelihood, the villager acquiesced precisely because she did not have the kind of higher-level leverage the mining company had.

${ }^{71}$ M. Umar, C. Derashid, I. IBrahim, What Is Wrong with the Fiscal Social Contract of Taxation in Developing Countries? A Dialogue with Self-Employed Business Owners in Nigeria, cit., p. 7. 
Such access provides these officials with precisely the kind of fodder they need to exploit outsiders, as they ignore both the letter and the spirit of national-level laws.

The result is two-fold. Most immediately, civil servants tend to demonstrate an unwillingness to follow or enforce the national law because they are not actually hired to do so. Second, virtually any economic surplus created by individuals or businesses is subject to expropriation —or the threat of expropriation — which has the potential to substantially inhibit economic development in failed states ${ }^{72}$.

\subsection{The Citizen and Business Owner}

In the preceding two subsections, we described why the leadership and civil servants are incentivized to break national laws in failed states. In this subsection, we similarly describe how citizens (and businesses), the largest group in failed states, are also incentivized to defy national law ${ }^{73}$. We focus on three reasons to ignore national law: (1) when citizens do observe national law, they get entangled with national government officials who, as described in the last section, are likely to exploit those citizens, (2) many citizens will have a viable substitute for national law, which is local law, and (3) following the national law often requires absurd measures on the part of citizens and businesses.

It is worth keeping in mind throughout the section that, in addition to these three factors, citizens clearly recognize that government actors - from the leadership to the lowest functionary-disregard both the letter and the spirit of established laws. As one of Umar et al. 's Nigerian business interviewees stated: " there are copious provisions in the constitution to protect ordinary citizens but the law and the judiciary have been hijacked by the ruling elites to serve their selfish interest. 'As it is currently, the law doesn't protect the ordinary people.' ... [Furthermore, this participant] did not blame the auditors for negotiating bribes during audit visits because it is the general trend in the

72 See G. Tullock, The Welfare Costs of Tariffs, Monopolies, and Theft, in "Economic Inquiry", n. 3, 1967, pp. 224-232 for a description of a similar process.

${ }^{73}$ Hereafter, we generally use "citizens" to refer to citizens and businesses for ease of exposition. 
society: 'How do you expect tax auditors to be different with the level of decadence in the society?"'74.

Turning to the first motivation for citizens to ignore national law, we note that adhering to national laws frequently requires something of citizens that will seem trivially obvious: citizens and businesses are forced to interact with state agents. The implications of this observation are however far from trivial. For example, paying taxes means delivering money to officials; filing reports of lawbreaking behavior-such as theft, corruption, or smuggling - requires interacting with police or military agents; and complying with various other regulations likely requires the application and receipt of permits and official inspections. Once an individual engages with national-level officials, that individual becomes known to those officials and also becomes a potential target for exploitation. Citizens, acutely aware of this process, will likely avoid the state whenever possible. This means taxes may not be submitted, reports of theft will not be made, and regulatory permits will not be applied for.

Some groups take extreme measures to avoid the state. Scott provides accounts of Southeast Asian citizens who fled to the mountainous region between Laos and Afghanistan, which is roughly the size of Europe in order to avoid state expropriations ${ }^{75}$. Some groups even adopted languages that were difficult to decode, and some abandoned literacy altogether in order to make it more difficult for governments make claims on them. Similar groups certainly exist deep in the forests, deserts, and mountains across failed states. Indeed, in many cases, the seat of the central government is located sufficiently far from the hinterland that groups in these distant regions are able, effectively, to ignore national-level laws.

Instead of moving away, citizens might also cooperate directly with rebel groups ${ }^{76}$. These rebel groups, at the very least, frustrate the state

${ }^{74}$ M. Umar, C. Derashid, I. IBrahim, What Is Wrong with the Fiscal Social Contract of Taxation in Developing Countries? A Dialogue with Self-Employed Business Owners in Nigeria, cit., pp. 6-7. This experience of the Nigerian business owner underscores Leoni's insistence that the mere existence of (official) laws hardly guarantees the normative properties we associate with the rule of law; see our footnote 9, above. See B. LEONI, Freedom and Law, p. 9.

75 J. C. Scott, The Art of Not Being Governed, New Haven, Yale University Press, 2009.

76 We use the word "cooperate" rather than "support" rebel groups because many rebel 
from accessing certain areas because the threat of conflict may be an effective means for a weaker actor (the rebel group) to deter a stronger one like the national state ${ }^{77}$. Rebel groups are moreover illegal, ipso facto, from the perspective of national law, and their very existence symbolizes the lack of respect for national law.

These rebel groups also have the potential to wholly or partially replace state services in the areas where they operate; they might even be more effective than the state at providing some services ${ }^{78}$. For example, when the Islamic State (ISIS) conquered new territory in Iraq and Syria, it took over public services and called public servants back to their offices and ordered them to work ${ }^{79}$. It has been suggested those public servants tended to work harder than before, as the punishments threated by ISIS for insubordination were far worse than they had been previously under Iraqi or Syrian governments ${ }^{80}$. Another example comes from a north-western prefecture of the Central African Republic. A rebel group there, known as Revolution Justice, took over most of the state jobs, claiming the government was not performing them adequately ${ }^{81}$. In such instances, local law is created and enforced by rebel groups substituting for laws promulgated by the national government.

Indeed, even when individuals have not moved away or faced rebel groups that prevent the government's interference, they frequently rely upon local rules enforced by rebel groups, tribes, clans and religious orders $^{82}$. Informal tribal systems are frequently more significant, respon-

groups are clearly not voluntary organizations that an individual can easily resist if she wishes. As such, individuals who cooperate with rebel groups may not actually be supporting them, but they may prefer to engage with them over state agents.

${ }^{77} \mathrm{G}$. Tullock, The Edge of the Jungle, in C. Rowley (ed.), "The Selected Works of Gordon Tullock: Vol. 1. Virginia Political Economy”, Indianapolis, Liberty Fund, 2005 , p. 312.

${ }^{78}$ Of course, rebel groups may not provide any services and merely extort and exploit citizens absent laws enforced by the central state. See, for example, M. CHARLES, Colombia's New Narcos Set Up Intricate Extortion Racket in Vacuum Left by Disbanded Farc, in "The Telegraph", 12 May 2019. Charles describes how various gangs of criminals extort and tax the populace. No benefits are mentioned.

${ }^{79}$ R. Callimanchi, The ISIS Files, in "The New York Times", 4 April 2018.

${ }^{80}$ R. CAllimanchi, The ISIS Files, cit..

81 T. CARAYAnNIS, L. LOMBARD, Making Sense of CAR: An Introduction, in T. CARAYANnIS, L. LOMBARD (eds.), "Making Sense of the Central African Republic", London, Zed Books, 2015, p. 9.

82 S. Michalopoulos, E. Papaioannou, On the Ethnic Origins of African Development: 
sive, and trustworthy than formal governments in Africa. These smaller subgroupings effectively operate as viable substitutes for national law.

Citizens and businesses are also routinely forced to rely on their own resources and ingenuity for services that are often associated with the state. Umar et al. provide multiple examples of business owners who resisted the entire notion of "owing" taxes because they were themselves providing most of the services the state would typically provide. In one Nigerian business owner's words, "What do you mean by tax? I am sponsoring two children's education abroad because of incessant strikes in our universities, there is no public water in my house so I operate a personal bore hole, I power my business with a private generating set. Do you know how much I spend on all these? What tax do you want me to pay?" 83 . And another who detailed how he runs generators to power his business because there is no public power supply suggested, "Most of the profit goes into providing power. My children are all in private schools and this takes millions of naira annually, I do not have money to pay as tax-even if I have, why should I pay? ${ }^{84}$.

We do not presume that local groups are purely voluntary organizations: local groups can also "tax" citizens through a mix of voluntary and non-voluntary consent. However, unlike the national government, they likely provide some level of rudimentary public services and tax according to a "plan known to the households" 85 . In other words, there is quite likely a greater correspondence between "taxes" and collective "services" than in the case of the national government ${ }^{86}$. Such a taxservice plan - which we might think of as a local "constitution" - can

Chiefs and Precolonial Political Centralization, in "The Academy of Management Perspectives", n. 1, 2015, pp. 32-71.

83 M. Umar, C. Derashid, I. IBrahim, What Is Wrong with the Fiscal Social Contract of Taxation in Developing Countries? A Dialogue with Self-Employed Business Owners in Nigeria, cit., p. 5.

${ }^{84}$ M. Umar, C. Derashid, I. IBrahim, What Is Wrong with the Fiscal Social Contract of Taxation in Developing Countries? A Dialogue with Self-Employed Business Owners in Nigeria, cit., p. 6.

85 R. SANCHEZ DE LA SierRa, On the Origin of States: Stationary Bandits and Taxation in Eastern Congo, in "Journal of Political Economy", n. 1, 2020, p. 10.

86 As a matter of fact, such behavior at the local level is consistent with the "benefits principle" of taxation in economic theory, which is based on the idea that those who benefit from a publicly-provided good or service pay for it. In the case of failed states, benefits are more likely to be provided by the local entity than the national one. 
be conceived as shared norms and rules. These local systems of rules, by their nature, are not national law, and following such localized rules will frequently bring citizens into noncompliance with national law.

Even if local systems of rules are not in conflict with national law, they may indirectly encourage noncompliance with national law precisely because they are local rather than national. Local rules in failed states are often better at constraining local actors than national-level ones. However, local rules are typically not binding for outsiders. Worse still, out-group members know that agents meant to enforce national laws - such as judges, police, other civil servants, and higher officials - are often unable to enforce these laws and that these officials can be bought off. Thus, the level of political organization with jurisdiction to stop out-group members from predation - the national lawis non-existent or ineffectual as a matter of practice. Individuals within local groups will therefore perceive most "outsiders" as threats, unable to be deterred by either local or national institutions.

Since local structures are typically small-scale and cannot fully deter out-group members from acts of predation, individuals will use weapons and other illegal means that break national law in order to protect themselves, their family, and their resources. For example, many failed states have highly restrictive formal gun laws. Sudanese law states: "No person shall possess, use or carry any arms unless he is in possession of a valid license from the licensing authority empowering him to possess, use or carry such arms" 87 . Despite an estimated two million fire arms in civilian hands in Sudan, as of 2007, there were less than 10,000 registered firearms ${ }^{88}$. Clearly, there were millions of individuals breaking the Sudanese national law that required the licensing and permitting of firearms.

These Sudanese firearm laws exemplify our last reason citizens do not follow the law: the laws of failed states are often absurd. Contrast firearm controls in developed, largely law-abiding western nations with

87 C. Flew, A. URquhart, Strengthening Small Arms Controls: An Audit of Small Arms Control in the Great Lakes Region and Horn of Africa, 2004. Available at: https://www.saferworld.org.uk/resources/publications/41-strengthening-small-arms-controls (last accessed: June 2019).

${ }^{88}$ See Human Security Baseline Assessment HSBA, Supply and Demand: Arms Flows and Holdings in Sudan. Small Arms Survey, Geneva, 2009, p. 9. Available at: http://www.smallarmssurveysudan.org/fileadmin/docs/issue-briefs/HSBA-IB-15-arms-flowsand-holdings-in-Sudan.pdf (last accessed: July 2019). 
those in a failed state context. In the West, crime is relatively infrequent, police response tends to be swift and courts are largely perceived as fair. In this environment, controlling firearms is a sensible policy to many and compliance is usually high. However, in the context of a crime-ridden failed state, like Sudan, where the police are unjust and slow (at best) and the courts are corrupt, a gun can be viewed as a necessary, and therefore legitimate, means of self-protection. Prohibitions against owning a firearm are essentially prohibitions against self-defense 89.

The World Bank's Doing Business Indicators lists many laws and regulations, by country, that simply cannot be followed in practice ${ }^{90}$. Table 3 includes laws that would be so burdensome to comply with that many surely choose not to. Table 4 includes examples of laws that cannot possibly be followed because of how costly, and even illogical, they are. Indeed, so many laws and regulation in these two tables are so costly that massive, society-wide law breaking must surely be the norm.

Table 3 - Laws Unlikely to be Followed.

- Firms in Eritrea, Equatorial Guinea, the Central African Republic, Columbia, and Afghanistan would owe more than $70 \%$ of their profit in taxes.

- In Liberia and Madagascar, it takes more than a year for a firm to get connected to the electrical grid.

- In Haiti, it takes 97 days to start a business.

- In Afghanistan, the cost of acquiring construction permits amounts to $73 \%$ of a warehouse's value.

- The cost to register property in Syria is $28 \%$ of the property's value, and, in Cameroon, it is nearly $19 \%$.

- The cost of having a contract legally enforced is over $75 \%$ of the claim in Comoros, Zimbabwe, Central African Republic, Burkina Faso, Democratic Republic of Congo, and the Solomon Islands.

- It takes more than four years to settle a contract enforcement in the courts in GuineaBissau and Afghanistan.

Source: THE World BANK, Doing Business, cit.

${ }^{89}$ Shortly after becoming a newly independent state, South Sudan passed a law similar to North Sudan that forbade the carrying of firearms without a license. See South Sudan Firearms Bill, 2016. Available at: https://www.gunpolicy.org/documents/6446-south-sudanfirearms-bill-2016/file (last accessed: July 2020). Reliable data on the number of licenses issued by South Sudan does not exist, but there are an estimated 1.2 million civilian firearms there. See the Human Security Baseline Assessment HSBA, Supply and Demand: Arms Flows and Holdings in Sudan. Small Arms Survey.

90 The World Bank, Doing Business, New York, The World Bank. Available at: https://www.doingbusiness.org/en/data (last accessed: July 2020). 
Table 4 - Laws that Cannot be Followed.

- Liberia, Zimbabwe, Haiti, Kenya, Mozambique, the Central African Republic, and Togo all require a minimum wage that is $100 \%$ (or greater) of the value added per worker, meaning firms are legally required to pay employees more than they bring in value to the firm.

- $\quad$ Firms operating legally in Comoros would owe $220 \%$ of their profit in tax.

- The cost of enforcing a contract dispute through the state would be $163 \%$ of the value of the claim in Timor-Leste, and over $100 \%$ of the value of the claim in Papua New Guinea and Cambodia.

Source: THE WORLD BANK, Doing Business, cit..

Facing such hurdles, many businesses simply choose to not follow national law, resort to extra-legal means to enforce contracts, and operate in black or grey markets. In other words, business owners are incentivized to break the law. The laws published by the government are often nonsensical, and encounters with state agents are frequently predatory. Citizens are therefore likely to avoid the state where possible. Their continual avoidance of the state will, itself, contribute to the ongoing subversion of national rules, resulting in the high rates of noncompliance that inhibit the development of a respected system of national law. The result is persistent noncompliance with national laws and further entrenchment of the norm that national laws need not be followed.

\section{Conclusions}

When comparing developed to developing countries, observers frequently overlook that highly-functioning formal institutions of wealthy nations require an informal social norm to encourage compliance with those institutions. We claim failed states lack such a fundamental social norm, and we provide suggestive evidence from citizen surveys in failed states, experiments in small-scale societies, and an analytic narrative discussing the dynamics of national rule following in failed states.

Specifically, our analytic narrative explores the incentives facing individuals in three key socio-economic groupings - leaders and ministers, civil servants, and citizens/businesses - and the ensuing social dynamics that entrench a non-adherence norm. Leaders manipulate the law to suit their own ends and they select ministers based on the like- 
lihood the latter will remain loyal; they are not selected based on their willingness to follow the law. Ministers are thus free to break the law, and many do so in pursuit of enrichment. Mid-level civil servants similarly break the law to provide for themselves due to similar institutional incentives and low pay. These state officials are part of a pervasive, and ongoing, effort to harass citizens and businesses in order to expropriate resources. Finally, citizens and business owners avoid the government whenever they can and are expected to ignore the plethora of nonsensical laws issued by the national government. These groups also recognize that civil servants and senior officials do not follow their own laws. We provided a number of anecdotal examples throughout our narrative to support these claims.

We argue the state is "failed" because virtually no one, in any of our three groupings, has reason to support a society-wide rule of law. A species of prisoner's dilemma arises: even if individuals in one group suddenly - and unrealistically_-began to conform to the letter and spirit of the rule of law, there is no reason for individuals in the other groups to do so. This, we conclude, explains why state failure seems to be so persistent.

By adopting our simpler redefinition of failed states as nations with a predominant norm of noncompliance with national laws, the common list of shortcomings in failed states - autocratic regimes, endemic conflicts, a mismanaged economy, chronically weak and inept security services, rampant corruption, and low-paid civil servants - is repositioned as a set of outcomes of rules being ignored, rather than as an explanation for the failure. This is important conceptually because so many international relations and development scholars look for solutions to state failure in bolstering precisely these metrics: better public services, better pay for public servants, and indeed better rules all around. Our view suggests that informal institutions underpin the set of outcomes observed, such as poor public services and abysmal economic performance. Thus, focusing policy attention on these outcomes, looks to us, like treating the symptoms and not the underlying causes ${ }^{91}$.

91 We would be remiss if we did not acknowledge that the formation and maintenance of social norms and formal institutions are endogenous (see, for example, J. BUCHANAN, The Limits of Liberty: Between Anarchy and Leviathan, cit., pp. 117-119). Over a long enough timeline, leaders, civil servants, and citizens could develop a norm to follow na- 
Our argument implies approaching international interventions and other external attempts to strengthen government "capacity" with great caution, but for reasons quite distinct from normal criticisms of such interventions. Typically, critics such as Herbst and Brock et al. argue that external intervention further entrenches the inept and exploitative leadership or will not be implemented correctly ${ }^{92}$. This is a critique shared by Easterly who questions whether the right institutions can be implemented, or even whether external analysts know which institutions to implement in the first place ${ }^{93}$. He refers to such hubris as the "technocratic illusion".

While we fully agree with these critics, we reject interventions more fundamentally because they focus only on the formal institutional structure and are thus highly unlikely to change the underlying civil interactions. Without a change in the underlying propensity for individuals across society to self-adhere to formal institutions, efforts to reform the latter seem to be doomed to disappoint. The multitudes of civil servants and private citizens will continue to have a strong propensity to break the law when it suits them. As such, "better" laws will not change the behavior of civil servants and private citizens. The prediction that official reforms and external interventions - including military excursions and foreign aid - are likely to be futile in this subset of nations is, unfortunately, consistent with the stubborn persistence of failure there.

tional law and their formal institutions could come to exhibit a rule of law. However, our analytical narrative points to the many obstacles frustrating a speedy, robust establishment of such a rule of a law.

92 J. Herbst, Responding to State Failure in Africa, in "International Security", n. 3, 1996/1997, pp. 120-144; L. Brock, H-H. Holm, G. Sørensen, M. Stohl, Fragile States and Violence: The Limits of External Assistance, in "Global Dialogue", n. 1, 2011, pp. 111; L. Brock, H-H. Holm, G. Sørensen, M. Stohl, Fragile States: Violence and the Failure of Intervention, cit..

93 W. EASTERLY, The Tyranny of Experts: Economists, Dictators, and the Forgotten Rights of the Poor, cit.. 
Riassunto - Nell'intento di costruire modelli di "Stati falliti" molti studiosi di relazioni internazionali e di sviluppo concentrano l'attenzione sulle istituzioni formali che, ad avviso degli autori, possono essere considerate sinonimi di "rule of law". Gli autori ritengono invece che gli Stati falliti - e in modo particolare la loro durata - non possono essere compresi se non si prendono in considerazione le regole sociali informali sulle quali la "rule of law" si basa. Nel saggio tali regole, quando si tratti di Stati falliti, vengono trattate ipotizzando che non esista alcuna norma che imponga di conformarsi alla legge: in particolare si ritiene che i leader politici, i ministri, i funzionari e i cittadini degli Stati falliti siano privi di norme sociali generali che li sollecitino a conformarsi alla legge. In assenza di tali norme, le dinamiche socio-politiche producono inettitudine, autocrazie, burocrazie inefficienti e predatorie, abitudine diffusa alla violenza, e infine povertà. Il saggio si propone di spiegare il motivo per cui, nonostante i tanti interventi, il fenomeno degli Stati falliti sia tanto persistente: all'origine di esso, infatti, stanno fenomeni sociali profondi, che ne sono la causa e non la conseguenza. 